\title{
MORPHOLOGY OF TALANG MAMAK TRIBE DIALECT AT INDRAGIRI REGENCY OF RIAU PROVINCE, INDONESIA
}

\author{
By Seno H Putra, Drs,.M.Pd.,Ph.D.,Prof \\ Linguistic Professor of The Islamic University of Riau, Pekanbaru Riau, Indonesia
}

\section{INTRODUCTION}

Not many people know about the Talang Mamak, an ethnic group in eastern Sumatra, Indonesia, who still live in the interior of the Indragiri Hulu regency in the Riau Province of Indonesia. However, both culture and language can be investigated and developed, in order to contribute to the world-wide society. Until now, however, many people, including linguists and anthropologists, have not yet investigated the unique characteristics of the Talang Mamak group. Although there have been a few scholars who have investigated these phenomena, the results have not been substantial. We note here only the studies by Sugio Hadi and Dalami Kari and Abdullah Manan and Syahdanur (n.d); see Collins (1995), especially on the words of Talang Mamak dialect, and Sulaiman a little focused on the Structure of Talang Mamak dialect (n.d); see also Collins (1995).

Indeed, there are some areas of the Riau Province where the studies of dialects have been done with much scholarly attention. The results of those studies are available not only to examine basic concepts and to assist in the development of the dialects themselves, but the studies could also contribute towards research, particularly by those who are interested in language studies. Among the studies are, for example, dialects of coastal areas in the Riau Archipelago (Dahlan, 1994), the dialects of orang Laut in the Riau Archipelago (Suwardi 1986), the dialects of Kampar (Dahlan 1983), the Morphology of the Rengat dialect of Indragiri Hulu (SenoH.Putra, 1998) and Morphological system of Bonai dialect (Ruswan, 1983).

Nonetheless, among Malay dialects little is known about Talang Mamak. However, according to Collins (1998), the dialects of minority people must be researched, because the dialects of tribal people, geographically split from mainstream social conditions, often display archaic elements of language, especially in vocabulary and morphology, and these elements may be useful for explaining features and classification of other dialects.

But, until today we still must ask: Why has the Talang Mamak dialect never been investigated? Why has it gotten less attention from regional or foreign scholars? Why have scholars been focused on the study of only some Malay dialects, especially in the parts of the Malay heartland, including in Riau itself, but not on the dialects of Talang Mamak, also a part of the Malay heartland? In other words, some scholars have been focused on the culture of TM, but only a few on the dialects of TM specifically.

With these questions in mind, the researcher has chosen to investigate the Talang Mamak dialect, especially focusing on the Morphology. There is another dialect, in this region, which has already been thoroughly researched, namely Rengat dialect (Seno H.Putra,1998), so this study will focus only on Talang Mamak, henceforth called TM. Geographically, Riau includes many variants of Malay that display differences and similarities from one area to the other, of course, all these dialects are part of the Malay language. Therefore, the focus of this research is on 
language use in some what informal settings, necessarily a dialect is the appropriate topic. As noted above, the TM dialect will form the basis of this study, or the main problem of this study is about the Morphology of TM dialect will be the main focused of this study.

\section{RESEARCH PROBLEMS}

The problems of this study can be formulated in two broad questions. First, what are the processes of morphology that pertain to nominal and verbal constructions of TM? Second, how do morphological processes interact with the syntax of TM?

\section{LIMITATIONS OF THE STUDY}

In this study, the researcher does not intend to report on all aspects of TM. Instead, this study is limited to the formulation of the problems (research problem) stated above and so that they can be investigated and analysed in depth. This has implications for what is to be investigated and how this study is to be conducted. Consequently, the main purpose of this study is to discover and describe the Morphology of TM dialect, particularly in the aspects of nominal and verbal constructions of TM, and the morphological processes that interact with the syntax of TM.

\section{PURPOSE OF THE STUDY}

This study uses a descriptive approach to collect, identify and describe the components of the morphology of TM. Since the components or the aspects of Morphology of TM are broad, this study is focused on only three tasks. First, to find out and describe the processes of affixation morphology, particularly in the formation of nouns and verbs. Second, to find out and describe the processes of between the processes of morphology and those of sentence structure in TM.

\section{HYPOTHESIS OF THE STUDY}

Although the aim of this study is to find and describe the Morphology of TM, by using a descriptive approach, this study also begins with the hypotheses of the study. The hypotheses of this study can be explained in three statements. First, there is a relationship between TM and other Malay variants. Second, there is a difference between TM and the other dialects of other area, including the variants spoken by other minority people in Sumatra, such as Kubu, Sakai, Suku Laut, and Bonai. Third, there are similarities between TM and the dialects of the other areas, including the languages or dialects of Kubu, Sakai, Suku Laut, and Bonai. Based on the three hypotheses above, therefore, this study, at least, can contribute to explaining the relationships that exist between TM and other Sumatra dialects, including Kubu, Sakai, Suku Laut, Bonai by delineating the similarities and differences among them. 


\section{SIGNIFICANCE OF THE STUDY}

As stated above with respect to the purpose of this study, this study is aimed at finding out and describing aspects of the Morphology of TM, but the results of this study can also contribute to further research, particularly because the study of TM in the aspects of Morphology that has not been much researched yet by scholars until now. With clear understanding of TM Morphology, Thus, this study can also contribute to those who are interested in conducting research about the Malay language, especially the dialects of minority people like TM, and the results of this study can contribute to linguistic studies.

\section{GENERAL DESIGN OF THE STUDY}

The design of this study is based on the methodology of qualitative linguistic research. The approach used in this study is to describe and analyse linguistic corpora, because, in carrying out this study, the researcher directly went to the field to collect the data through informal communication and interaction with the Talang Mamak dialect speakers as well as through formal elicitation and recording sessions. These efforts were undertaken became the main work of a linguist who wishes to analyse linguistic data found from the informants in the field. In short, the purpose of studying a dialect is to acquire accurate data through natural communication in the language in use (Bogdan, 1982; Punch, 2001:59).

In this study, although the researcher directly went to the field, the researcher also used a Talang Mamak assistant, especially to communicate and interact with the TM dialect speakers. During the field work, the researcher encountered difficulties in acquiring the data from the TM dialect speakers. The TM dialect speakers were very shy not only to talk freely, but also, they were reluctant to face and meet with an outsider, or someone who was not yet known to them. Therefore, in order to get the data for this linguistic corpus, the researcher was usually accompanied by the village head, Kumantan, a 51 year old man appointed village head by the Indonesian government. Its role in the field was to assist the researcher to obtain the data, by persuading the TM dialect speakers to communicate either with him or with other TM speakers, so the verbal intonation could be noted and tape-recorded.

In addition to the field assistant, the researcher also used two other assistants to obtain the data in the field. The two other assistants were indigenous TM people who have interacted more frequently with other people in Seberida; moreover, they had higher education, for example, one assistant was a junior high school graduate and the other a senior high school graduate. Those assistants, furthermore, still maintained proficiency in and knowledge of their own language and culture. The two assistants helped the researcher gather the linguistic data from the informants in the field and then acted as translators and assistants for the transcriptions of the data. They also assisted in the descriptive analysis of the discourse of the TM dialect.

During the elicitation sessions, the researcher and Kumantan asked the informants to speak freely, for example, about their daily activities, their experiences, or about the TM social and cultural problems. By using such a research design, and become the researcher was accompanied by the village head (Kumantan), the researcher was able to acquire the data 
smoothly. Because Kumantan is a person honored by the TM people, fieldwork was made possible by his participation. Moreover, local tradition requires that every researcher or an outsider who wants to visit or investigate the TM people must report with Kumantan. It must be admitted that the presence of the important local leader and the researcher himself may have had an important or the data collected. The other informants serve as translators to explain the texts and data obtained in the field. These texts were written that is transcribed, then the informants translated the texts of TM into Indonesian.

\section{SELECTING THE TM INFORMANTS}

The population chosen for this study was the Talang Mamak society in the Seberida district. However, since the population of this minority people is rather large, perhaps 6,983 people (Departemen Sosial Kab. Inhu, 1992), only 15 persons were selected as informants, representatives of the population of the whole Talang Mamak society. 15 persons of TM society as a sample of the whole of TM in Seberida district, these informants were selected based on the criteria, for example, age, sex, level of education, the use of dialect, and reduced contact with outsiders. The characteristics of selected informants are as follows: There were 7 women and 8 men whose ages were between 30 to 50 years. The researcher chose these informants, because they were able to communicate fluently, that is, they were able to use the linguistic elements of their language in daily communicative use.

Although this is a small sample used in this study, the most important thing is how the linguistic data was acquired based on the speech of TM speakers. In this case, as Labov (1975) was of the opinion that in linguistic research, the researcher may use only one informant to obtain a linguistic corpus in the field. In addition to this, the were reasons for only taking 15 informants in this study. First, these informants were broadly representative of TM population still settled in the Indragiri Hulu regency. Second, the Seberida district is a part of regency where a relatively large number of TM people live rather than other areas of Indragiri Hulu, such as Rengat Barat district and Keloyang district. Third, the TM people in Seberida, as well as Rengat Barat, and Keloyang districts until now have not been researched by any scholars, particularly with respect to their dialects and culture; so, even this small sample of 15 speakers, it will be possible to shed light on a larger problem. Only two dialect speakers completed elementary school; while the others had no formal education. This seems to reflect the general level of education among two aged thirty years old above.

As shown above, only two dialect speakers completed elementary school; while the others had no formal education. This seems to reflect the general level of education among those aged thirty years and above. Moreover, two TM speakers who had formal education has a little different knowledge from other speakers. In this case, he is also a Shaman (Bomo) in the TM people. Therefore, he was usually asked by the TM people to treat sick people (traditional medicine), particularly in the Talang Jerinjing. Mawan is the uncle of Panjatan who was replaced him to be a Shaman for the TM people. In order to treat sick people, they usually interact with other people out of TM people, so that they are also able to use another dialect, especially Rengat dialect. So, although these speakers of TM are also able to use another dialect, for example, Rengat dialect, they still maintained their own dialect, that is, TM dialect used in daily life. 
All these informants were chosen for this research project, because they were indigenous people of TM; in their daily activities, they use their own dialect and culture. They apparently have not been significantly influenced by other dialects and cultures in the broader society, in this case, for example, the dialects of Rengat, Taluk Kuantan, Indragiri Hilir, Kubu, Pelalawan, and Minang. Geographically, these areas are also close to the area of TM society. To prove that these informants were not influenced by other dialects, firstly, the researcher asked them to communicate with TM dialect; the second one was the researcher asked them to pronounce the things, such as a part of the body and the furnitures in their houses (the researcher pointed something, then still use TM dialect; and the third one was the researcher asked the village head of TM to choose the TM informants who are never out of, or never interact with other community. In other words, all these informants of this study still live in their own village and community. In short, they were really indigenous people of TM who were selected to be the sample of this study.

\section{BUILDING THE TM CORPUS}

There were two major procedures to develop and expand the TM corpus used for this study. First, data were obtained by asking each speaker of TM to speak freely about his/her experiences and daily activities. Sometimes he/she was also asked to speak about the traditional lifestyles of the TM community. These monoloques were recorded and later transcribed to develop a corpus of discourse reflecting the complexities of the morphology and syntax of TM.

The second major procedure was more formal and involved the use of a tested research instrument. Collins developed a lexical questionnaire of 465 items (in Malay and Indonesian) used as a survey instrument in Borneo. This rather long questionnaire, an elaboration of the Swadesh 200-item wordlist, is based on both semantic fields (plants, animals, body parts, both technology) as well as word classes (verbs, adjectives, numerals, pronouns). By eliciting the items of this questionnaire, the researcher gained familiarity with the phonological and morphological systems of TM.

Furthermore, in this study the researcher used two mechanical devices to support the acquiring of the data. First, a small cassette tape recorder was used to record informal communication, for example, at home or in shops, and more formal speech acts, such as ritual ceremonies of the TM society. Such techniques have been used by thousands of scholars (Labov, 1975) and Stubbs, 1985). Second, a camera was used to take photographs showing the conditions of TM society in the Seberida district. This was intended only as a documentation of the study.

\section{FIELD COLLECTION METHOD}

As noted above, the researcher collected the data in the field. Some informants (speakers) were asked to speak freely, and were recorded. On other occassions, however, two or more speakers were asked to talk to each other about their daily activities and experiences. This technique has been used for several decades in the study of Malay dialects. As Collins (1987:30) stated, "two native speakers at the same village are asked to talk about their own daily activities (what they like to talk about), for example, fishing, and so on". As these talks are recorded, the researcher can become involved in communicative interactions. 
The initial visit was to select a research site, observe potential informants and contact the chief assistant, Kumantan; Subsegment visits were undertaken to make recordings as well as to elicit the questionnaire discussed. Each of the data collection visits were day-long trips to specific location in the field.

As Salimi (1991), the data for this research were gathered mainly in face to face interviews and conversations with speakers (informants). This means that the procedures for investigating the nature of phonological and morphological variants in a given community involved the technique of elicitation data, such as interviews, use of questionnaires. Moreover, the interview method and participant observation procedures have the advantage of enabling the researcher to directly observe the actual quality of relationship that exist within the informants; while questionnaires approach is to construct the information.

"... The interview is one of the main data collection tools in qualitative research. It is a very good way of accessing people's perceptions, meanings, definitions of situations and constructions of reality. It is also one of the most powerful ways we have of understanding others, and interview has a wide variety of forms and a multiplicity of uses, as well as the most common type of interviewing is individual, face to face, or face to face group verbal interchange (Punch, 2001:175)". In other words, in order to understand other persons constructions of reality, we would do well to ask them in such a way that they can tell us in their terms and in depth which addresses the rich context that is the substance of their meanings.

\section{DATA ANALYSIS METHOD}

In order to analyse the data obtained from the informants in the field, four techniques were used. First, the spoken data of the linguistic corpus were transcribed into semi- phonemic texts. Second, the researcher tried to find out and describe the questions of the formulation of the problems of the study; for example, (1) the question of the process of morphology formation in the aspects of nouns, verbs, and adjectives of the TM dialect; (2) the researcher attempted to find the relationship between the morphology processes and the sentence structure of TM dialect. Lastly, all the transcribed data described into the texts were re-read and re-examined to ensure the accuracy, validity, and reliability of the linguistic corpus of the Morphology of the TM dialect. Consequently, to re-examine all of the transcribed data, the researcher used one of his assistants to read and translate the material into Indonesian. In the data analysis of TM dialect speakers, in this case, the researcher and the assistants worked together in both collecting data from TM dialect speakers and analysing the data, especially to translate from TM dialect into local Malay or Indonesian. Moreover, if the researcher encountered difficulties about the meaning of TM words or structures, the assistants usually helped to translate these words and structures. 


\section{RESULTS AND DISCUSSION}

The results of this study is focused to the main problems of this research, that is; first, the processes of morphology that pertain to nominal and verbal constructions of TM dialect; Second, the morphological processes involved in inflectional and derivational affixes in TM; and third, the morphological processes interact with the syntax of TM. The examples of TM dialect are presented below.

\section{Morphological Process}

\subsection{Prefixation Forms}

\section{a) Prefixation that yields nouns}

Prefix $\{$ pa- $\}$ combines with adjective forms to become 'a person characterized by the base. Some affixes that yiled nominal forms have been identified, although only a few of them appear frequently. The prefix $\{$ pa- $\}$ is attached to any base form, functions to form nominal. The meaning of this prefix indicates someone who is characterised by the base. For example, /cadi?/

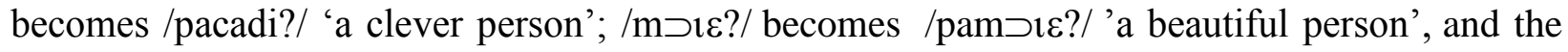
allomorph of $\{\mathrm{p} \partial \mathrm{N}-\}$ also appeared in the $\mathrm{TM}$ dialect determined by the initial sound of the roots, for example, vowel /i/, /e/ and consonants $/ \mathrm{b} /, / \mathrm{m} /$, and $/ \mathrm{s} /$ to form nominal form in the TM dialect. According to the categories of words, only a few word bases of adjective and verb forms

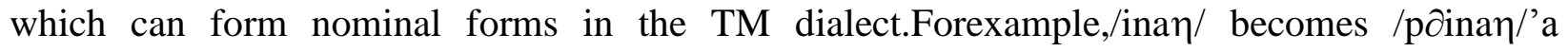

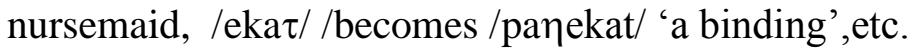

\section{b) Prefixation that yields verbs}

The prefix $\{\mathrm{pa}-\}$ can be added to a verbal base to yield a causative verbs, where this prefix derived from verbal, nominal, and adjective base forms indicating transitivity or action of the word forms.

For example, the prefix $\{\mathrm{pa}-\}$ verbal form in /tampu/ becomes /patampu/'to cause someone to be learner', /inca?/ becomes /painca?/to cause someone to be a joke',etc.

\section{c) Prefix $\{$ ba- $\}$.}

Prefix \{ba- $\} 1$.This prefix combines with verbal base forms to form intransitive verbal. The grammatical meaning of the derived can be 'a stative aspects', or may be glossed as characterised by the verb base. For example,/b $\partial \mathrm{ka} /$ becomes /b $\partial \mathrm{b} \partial \mathrm{ka} /$ 'to burn,/gugu?/

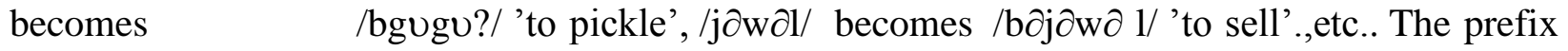
$\{b \partial-\}$ derived from nominal bases that can change to become 'intransitive verbs' indicating 'an

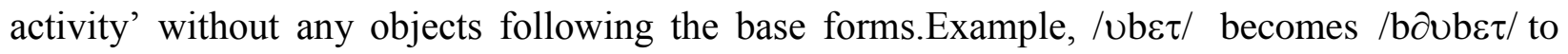
take medicine, /paran/ becomes / boparan / 'to have a floor', etc. 


\section{d) Prefix $\{$ di- $\}$}

The prefix $\{$ di- $\} 1$ is a verb forming with verb base acts as both category changing and category maintaining. In this construction, it functions as a 'passive voice'. /anta?/ becomes /dianta?/' to be collided into,/jidai/ becomes /dijidai/'to be struct'. The prefix \{di-\}2 also modifies 'passive voice', the meaning of this construction as an action of the person. Example, /kapen/

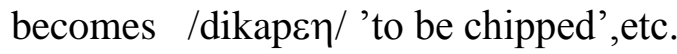

\section{e) Prefix $\{k \partial-\}$}

This prefix combined with verbal bases denote either active intransitive or transitive verbs, which have meaning as an event or situation which is unexpected or unpredictable.Examples,/santa?/ becomes $\quad / k \partial$ santa?/'to stumble'

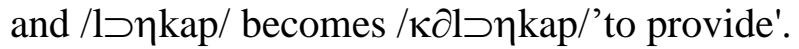

\section{f) Prefix $\{$ ta- $\}$}

Verbal bases are formed with this prefix denote intransitive or transitive verbal roots, and the meanings of this prefix are accidental, or agentless and unexpected.Examples,/campa?/'to fall '/tacampa?/, to fall down/tataga?/to stand up'. Others take the prefix $\{$ t $\partial-/$ in TM dialect as /tzkumpol/.'to collect'.

\section{g) Prefix $\{$ maN- $\}+$ transitive verbs}

This prefix functions as transitive verb marker expressing dynamic or progressive action, for

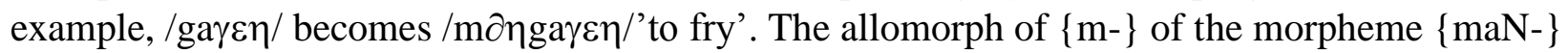

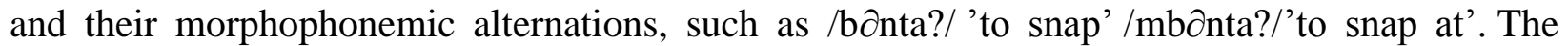
other prefix $\{\mathrm{maN}-\} 2$ also appeared in TM dialect to yield statives verb indicating intransitive verb, i.e., /bumb $\supset \eta /$ 'be big' /mbumb $\supset \eta /$ to be big'.

\section{h) Prefix $\{s \partial-\}$}

This prefix can be formed with noun and adjective, i.e., /tingi/'high' / becomes /sətingi/'to be very high', another one indicates 'location' etc., /bつla/'next' becomes / $b \supset l a /$ ' to be next'.

\subsection{Suffixation Forms}

The morphological process attached at the end of roots or stems of a language (King, 1968; Sturtevant, 1973). In this study only two kind of suffixes found in TM dialect denoting category maintaining or category-changing if they co-occurs with verb base. For example, the suffix $\{-a n\}$ added to the verb base indicates a repeated activity, like /c $\supset \mathrm{l} \supset \mathrm{p} /$ 'to dip' becomes /c $\supset \mathrm{l} \supset \mathrm{pan} /$ 'to 
cause someone to dip something', while suffix $\{-i\}$ functions as 'passive transitive' and denotes a complete action done by someone, such as /ulah/ becomes /ulahi/ 'be acted'.

\subsection{Circumfixed Forms}

a) The circumfix \{pa-an\} interacts with verbal forms to yield abstract or general nouns, i.e., /tampa?/ 'to appear' becomes patampa?/'appearance', while $\{\mathrm{paN}-\mathrm{an}\}$ interacts with verbal forms indicate a place where the process occurs, i.e., /tili?/ becomes /panili?an/'the place where the one can peer, a peephole'.

b) The circumfix $\{$ maN-an $\}$ denotes a process of doing something repeatedly, and the verbal roots yield transitive verbs. Examples, /taga?/ becomes /managa?an/ 'to make something erect'; while $\{\mathrm{m} \partial \mathrm{N}-\mathrm{i}\}$ functions as active transitive, and grammatically links 'an agent' with the result

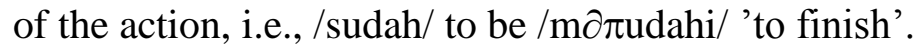

c) The circumfix $\{\mathrm{m} \partial \mathrm{N}-\mathrm{i}\}$ functions as active transitive, and grammatically links 'an agent', with

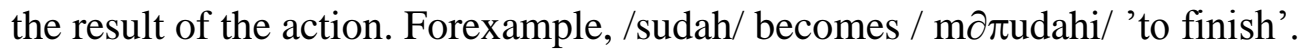

d) The circumfix $\{$ di-an $\}$ derived from the variety of roots, like nouns, verbs, and adjective bases. The function of this circumfix denotes the passive voice, and it means that someone acts

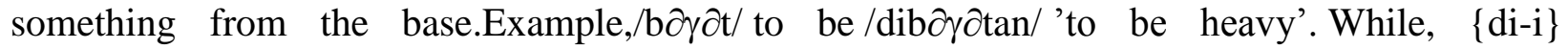
indicating 'passive transitive', where someone acts something derived from the base, such as /ulah/ to be /diulahi/ 'to be acted'. Besides the circumfixes above, the TM also has circumfix $\{\mathrm{s} \partial-\mathrm{an}\}$. The meaning of the word forms may be glossed as 'sameness in property, or state. See

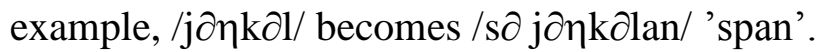

\section{The Role of Morphology in Transitive Sentences}

\subsection{Active transitive sentences}

In TM dialect, active transitive sentence is the sentence whose subject functions as 'an agent' or an actor'. In other words, active transitive sentences in TM dialect consist of 'noun phrase as a subject' and 'verb phrase as a predicate'. Moreover, the constructions of TM dialect in active transitive sentences are mostly the same forms as other Malay dialects or Malay language. This means that the structure of these sentences are almost the same forms as the dialects surrounded it, for examples, Rengat dialect, Pelalawan dialect, Taluk Kuantan dialect, etc.

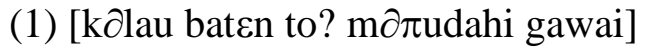

if village head for pre+finish wedding party.

As for the village head, it is he who concludes a wedding party.

(2) [nan paleๆ utam $\partial$ yuma tu kayu]

That most important pre+make house that wood.

The most important thing about building a house is wood. 


\subsection{Passive transitive sentences}

In TM dialect, passive sentences can be constructed with two kinds of forms based on their structure: one with using 'd $\varepsilon$ ?' as prepositional phrase in one direct object, and another one without 'prepositional phrase'. Example, (1) [aku diawai de? sandal] 'I pre+slip by sandal (I

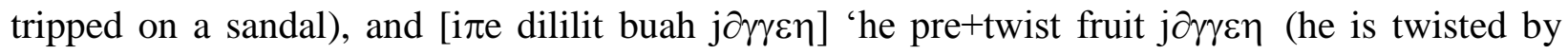
jereng).

\section{The Role of Morphology in Intransitive Sentences}

A few of verbal bases function as intransitive forms denoting 'an action of the verb in the subject', where the predicate is not followed by an object, except 'an adverb of place'. Here we

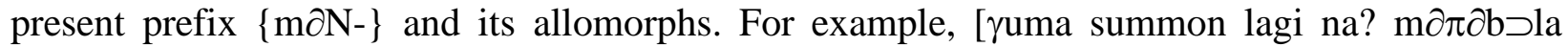
sitaw] 'house summon again want pre+besides there (Sumon's house is on the side over there)., etc.

\section{Stative Sentences with Prefixes}

Stative verb is one that is not normally used in progressive tense. Most stative verbs refer to 'state', not to actions or events (Swan 1988). From the investigated data, the several forms of stative intransitive sentences were found in this dialect. The stative sentences, in the TM dialect, express the condition in which somebody or something in circumstances.

\section{Reflexive Sentences}

The reflexive sentence is a combination of -self with one of the personal pronouns or with the impersonal pronoun one. The reflexive pronoun generally refers to an animate being, usually a person. The most common use of the reflexive pronoun is an object that 'reflects back' to the

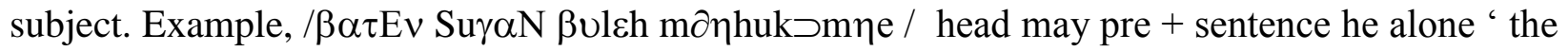
head of village himself may sentence him'

\section{Reciprocal Sentences with Prefixes}

Reciprocal sentence is the sentence which refers to 'given' and 'received' in return an mutual, or it expresses mutual action or relation from one to another (Thomson 1987). Example,popatah bolom kalah mônalah / 'proverbs not pre + defeat' ' proverbs have not even been defeated or formed short' .etc. 


\section{Conclusion}

In the morphological processes of TM dialect include prefixes, suffixes, and circumfixes. The prefixes encompasses prefixation that yields nouns and verbs; while, suffix consists of suffixation forms, such as suffix $\{-$ an $\}$ and $\{-i\}$.

In the section of inflectional and derivational constructions, i.e., inflectional constructions in TM dialect involves in prefixes $\{\mathrm{maN}-/ \mathrm{m} \partial \mathrm{N}-\},\{$ ta- $\}$, and the allomorphs of $\{\mathrm{m} \partial \mathrm{N}-\}$, such as $\{\mathrm{m}-\},\{\mathrm{n}-\}$, and $\{\mathrm{N}-\}$ which function to form active and passive voices denoting either 'an agent' or an action of person, and unintentional activity derived from the word bases. While, the derivational constructions consist of prefixes $\{\mathrm{k} \partial-\},\{\mathrm{p} \partial-/ \mathrm{p} \partial \mathrm{N}-\}$, which also function to form: verbal, nominal, and adjective forms. For example, in the derivational constructions, nominal bases become nominal forms, verbal bases performs, and adjective bases to be nominal forms after the process of derivational affixation. In short, all the examples presented in this section derived from various word bases of TM dialect. Moreover, a few examples of derivational forms with suffix $\{-a n\}$ and circumfix $\{k \partial-$ an $\}$ were also displayed in this section, where this suffix and circumfix followed by word bases to yield nouns and abstractness.

The morphology constructions of TM dialect are displayed in various forms of sentences. The role of morphosyntax with transitive sentences include active transitive sentences and passive transitive sentences; while, the role of morphosyntax with three prefixes, such as the prefixes $\{\mathrm{m} \partial \mathrm{N}-/ \mathrm{maN}\}$ and $\{\mathrm{b} \partial-/ \mathrm{ba}\}$ in the intransitive sentences. Still concerned with this section, three types of sentences also appeared in TM dialect, i.e., stative sentences with prefixes $\{\mathrm{b} \partial-\},\{$ ta- $\}$, and $\{\mathrm{maN}-\}$, and reflexive sentences with prefix $\{\mathrm{maN}-\}$ derived from various verbal roots, and the last of this section, reciprocal sentences with prefixes $\{m \partial \mathrm{N}-\}$ and its allomorphs, $\{\mathrm{ba}-\}$ and $\{\mathrm{di}-\}$ were also presented, and semantically, they denote reciprocal or repetitive action. 


\section{References}

Anderson, Stephen R. 1977. On the formal description of inflection. Proc. Chicago Linguistic Society. 13 (15-44).

Andaya, Y. Leonard. 1975. The Kingdom of Johor: London: Oxford University Press.

Aronoff, Mark. 1976. Word formation in generative grammar. Cambridge: MIT Press.

Ahmad, A. Samad. 1985. Kerajaan Johor-Riau. Kuala Lumpur: Dewan Bahasa Dan Pustaka.

Antilla, Raimo. 1972. An introduction to historical and comparative linguistics. New York: The Macmillan Company.

Blust, Robert. 1998.Rekonstruksi dan cabang-cabang bahasa Melayu induk. Kuala Lumpur: Dewan Bahasa dan Pustaka.

Banner, Laurie. 1984. English word formation. Cambridge: Cambridge University Press.

Chaedar, Alwasilah. 1987. Linguistik suatu pengantar. Bandung: Angkasa Bandung.

Chaika, Elaine. 1982. Language the social mirror. Rowley: Newbury House Publisher.

Collins, J.T. 1987. Dialek Melayu Serawak. Monograf Sejarah Bahasa Melayu. Kuala Lumpur: Dewan Bahasa dan Pustaka.

Collins, J.T.1995. Bibliografi dialek Melayu di Pulau Sumatra. Kuala Lumpur: Dewan Bahasa dan Pustaka.

Collins, J.T.1996. Khazanah dialect Melayu. Bangi: Universiti Kebangsaan Malaysia.

Collins, J.T. 1983. Dialek ulu Terengganu. Kuala Lumpur: Syarikat Prinsystem Sdn. Bhd. Taman Maluri.

Collins, J.T. 1986. Antologi kajian dialek Melayu. Kuala Lumpur: Dewan Bahasa dan Pustaka.

Collins, J.T. 1998. Malay, world language: A short history. The history of Malay Monograph series. Kuala Lumpur: Dewan Bahasa dan Pustaka.

Collins, J.T. 1994. Shifting patterns of language use in borneo. Borneo Research Council, Inc. 297-333.

Chomsky, Noam. 1969. Topics in the theory of generative grammar. Paris: Mouton.

Chomsky, Noam. 1957. Syntactic structures. Leiden: Mouton \& Co.

Drakard, Jane. 1999. A King of words: Language and power in Sumatra. Oxford: University Press.

Dahlan, Saidat. 1983. Hubungan bahasa dan dialek Melayu Kampar bagian timur dengan bahasa di daerah bekas Kerajaan Siak. Jakarta: Depdikbud, RI.

Dahlan, Saidat. 1994. Morfologi dan Sintaksis bahasa Suku Laut: Dialek dapur arang Kecamatan Belakang Padang Batam. Pekanbaru. tpt.

Dahlan, Saidat. 1997. Morfologi verba bahasa Sakai. Pekanbaru: tpt.

Ensiklopedi Indonesia. 1999. Jakarta.

Fasold, Ralph. 1984. English word formation. Cambridge: Cambridge University Press.

Froitzheins, Claudia. 1984. Language varieties and situation. A journal language in society 15 (4): 179-181.

Graff, S.D, and Stibbe, D.G. 1918. Encycopaedie van nederlandch-indie tweede druk. Leiden: N.V. v/H. E.J. Brill.

Geografi Daerah Riau. 1983. Geografi Daerah Riau. 1 (36-38) Jakarta: Proyek, IDKD.

Gumperz, J. John. 1971. Language in social groups. New York.

Gleason, A.A. 1961. An introduction to descriptive linguistics. New York: Henry Holt and Co.

Gani, Erizal. 2000. Tata Bahasa Jambi. Jakarta: Pusat Pembinaan dan Pengembangan Bahasa, Departemen Pendidikan dan kebudayaan.

Hassan, Abdullah. 1974. The Morphology of Malay. Kuala Lumpur: Dewan Bahasa dan Pustaka. 
Jakarimilena, Nico. 1979. Tapera affixes: A dialect of tanah merah Jaya Pura. Thesis Master: IKIP Malang.

Hill, Archibald. 1987. Linguistics. Washington: Voice of America Forum Lecturers.

Harimurti, Kridalaksana. 1989. Pembentukan kata dalam bahasa Indonesia. Jakarta: PT. Gramedia.

Halle, Morris. 1973. Prolegomena to a theory of word formation. dlm.Linguistic inquiry 16: 3-4. Hockett, Charles A. 1958. A course of modern linguistics. New York: Macmillan.

Jensen, John. 1995. Morfologi struktur kata dalam nahu generatif. Kuala Lumpur: Dewan Bahasa dan Pustaka.

J. Samarin, William. 1967. Field linguistics. New York: Holt, Rinehart and Winston, Inc.

Kuno, Susumo. 1980. Syntactic translation. New York:Mouton\&Co Academic Press, Inc.

King, D. Robert. 1969. Historical linguistics and generative grammar. New Jersey: PrenticeHall, Inc.

Kudo, Takayuki. 1992. Word formation in Aphasia: Evidence from Japanese kanji words. Journal of neorolinguistics. 13: 6-11.

Lyon, J. 1974. Introduction to theoretical linguistics. London: Cambridge University Press.

Langacker, Ronald W. 1973. Language and Its Structure: Some fundamental linguistic concepts. University of California at San Diego: hacourt brace Jovanovich, inc.

Labov, W. 1970. The study of language in its social context. J. Pride \& Holmes (eds). Harmonworth: Penguin.

Lass, Roger. 1991. Phonology. Cambridge: Cambridge University Press.

Lehmann, Winfred P. 1972. Descriptive linguistics: An introduction. The University of Texas. Random House, Inc.

Mahmood, Abdul Hamid. 1994. Sintaksis Dialek Kelantan. Selangor: Darul Ehsan. Percetakan Dewan Bahasa dan Pustaka.

Matthews, P.H. 1992. Syntax. Cambridge: Cambridge University Press.

Miller, J. 1986. Semantics and Syntax. Cambridge: Cambridge University Press.

Mela Latoa, M. Yunus. 1986. Tinjauan tentang porsi suku bangsa di Propinsi Riau masa kini satu hasil proses perkembangan. Pemda: Riau.

Muhajir. 1984. Morfologi Dialek Jakarta: Afiksasi dan Reduplikasi. Jakarta: Penerbit Djambatan.

Matheson, Virginia and Watson Andaya, Barbara. 1982. The precious gift: Tuhfat al-Nafis. Kuala Lumpur: Oxford University Press.

Nothofer, Bernd. 1996. Migrasi orang Melayu Purba: Kajian awal. Sari 14. Institute Alam dan Tamadun Melayu, UKM.

Nida, E.A. 1985. Semantics and syntax: Parallels and connections. Cambridge: Cambridge University Press.

Nida, E.A. 1946. Morphology: The descriptive analysis of words. Ann Arbor: Cambridge University Press.

Omar, Haji. Asmah. 1983. The Malay peoples of Malaysia and their languages. Kuala Lumpur: Dewan Bahasa dan Pustaka.

Pitsamai, Intarachat. 1987. Sintaksis predikat dalam bahasa Malaysia. Kuala Lumpur: Dewan Bahasa dan Pustaka.

Parera, Daniel. 1988. Sintaksis. Jakarta: PT. Gramedia.

Pleh, Csaba. 1990. An interdisciplinary journal of the language sciences (linguistics). .28 (6).

Punch, F. Keith. 2001. Developing Effective Research Proposals. London: SAGE Publications. 
Ramat, Paulo. 1990. An interdisciplinary journal of the language sciences (linguistics). 28 (6).

Ramlan, M. 1978. Morfologi: Suatu Tinjauan Deskriptif. Yogyakarta: Penerbit U.P. Karyono.

Ruswan. 1983. Morfologi bahasa Bonai. Pekanbaru. Tpt.

Seno, Putra. 1998. The Morphology of Rengat dialect. Pekanbaru: UIR Press.

Seno, Putra. 2001.Introduction to General Linguistics: Pekanbaru:Unri Press.

Seno, Putra.2005. Syntax and Semantics. Pekanbaru:Ur Press.

Seno, Putra.2000.Bahasa Melayu Purba.(Paper).

Seno, Putra.2014. The Ways of Scienctific Writing and Research Methodology.Pekanbaru:UR

Press.

Stubbs, Michael. 1985. Discourse analysis. Oxford: Basil Blackwell, Ltd.

Suwardi. 1986. Dialek bahasa orang laut. Jakarta: Pusat Pembinaan dan Pengembangan Bahasa. P\&K.

Schane, A. Sanford. 1973. Generative phonology. San Diego: Prentice-Hall, Inc

Samarin, J. William. 1967. Field linguitics. New York: Rinerhart and Winston, Inc.

Sejarah Daerah Riau. 1982. Jakarta: Proyek, IKDKD

Shellabear, W.G. 1967. Sejarah Melayu. Kuala Lumpur: Oxford University Press

Stork, F.C., and Widdowson, J.D.A. 1994. Learning about linguistics: An introduction workbook. London: William Clowes\&Sons Limited.

Sturtevant, E.H.1973. Linguistic change: An introduction to the historical study of language. Chicago: The University Press Oxford.

Schane, A. Sanford. 1973. Generative Phonology. San Diego: Prentice-Hall, Inc.

Suleiman, M. Saleh. 1990. Lexical conditioning of phonological variation: Language sciences. A word journal of the science of language. 12 (4).

Samsuri. 1988. Morfologi dan Pembentukan Kata. Jakarta: Departemen Pendidikan dan Kebudayaan.

Samsuri. 1994. Analisa bahasa. Jakarta: Erlangga.

Siregar, Ahmad Samin. 1984. Morfologi dan Sintaksis Bahasa Nias. Jakarta: Pusat Pembinaan dan Pengembangan Bahasa, Departemen Pendidikan dan Kebudayaan.

Salimi, L. Oladipo. 1991. A journal language in society. 22 (2).

Trudgill, Peter, Chambers. 1991. Dialects of English. NewYork: Longman.

Tomori, Ulu. 1977. The Morphology and Syntax of present-day English. London: Heinemann.

Tarigan, Henry Guntur. 1985. Prinsip-Prinsip Dasar Sintaksis. Bandung: Penerbit Angkasa Bandung.

Wardhaugh, Ronald. 1986. An introduction to Sociolinguistics. New York: Basil Blackwell.

Wahab, Abdul. 1991. Butir-butir linguistik. Airlangga University Press.

Wiskon, E. George. 1980. Let's write English: Revised Edition. New York. Litton Educational Publishing, Inc. 